Article

\title{
Explaining Effects of Transformational Leadership on Teachers' Cooperative Professional Development through Structural Equation Model and Phantom Model Approach
}

\author{
Woonsun Kang
}

Citation: Kang, W. Explaining Effects of Transformational Leadership on Teachers' Cooperative Professional Development through Structural Equation Model and Phantom Model Approach. Sustainability 2021, 13 , 10888. https://doi.org/10.3390/ su131910888

Academic Editor: Eila Jeronen

Received: 7 August 2021

Accepted: 26 September 2021

Published: 30 September 2021

Publisher's Note: MDPI stays neutral with regard to jurisdictional claims in published maps and institutional affiliations.

Copyright: (C) 2021 by the author. Licensee MDPI, Basel, Switzerland. This article is an open access article distributed under the terms and conditions of the Creative Commons Attribution (CC BY) license (https:// creativecommons.org/licenses/by/ $4.0 /)$.
Department of Social Studies Education, Daegu University, Gyeongsan-si 38453, Korea; wskang@daegu.ac.kr; Tel.: +82-053-850-4144

\begin{abstract}
This study aims to explore strategies for promoting Korean teachers' cooperative professional development in the context of Education for Sustainable Development (ESD). To this end, this study aimed to provide empirical evidence that may help in explaining the mechanism through which transformative leadership affects cooperative professional development. Based on research purposes, the author constructed a serial multiple mediation model that incorporates self-efficacy and attitudes as an underlying mechanism that explains transformational leaders' positive impact on cooperative professional development related to ESD. A total of 203 valid cases were used to test the hypothesized model. Furthermore, the author constructed structural equation modeling (SEM) and phantom models specifying the specific indirect effects of transformative leadership on cooperative professional development. In addition, bias-corrected bootstrapped point estimates for the specific indirect effects were calculated. The data were analyzed using SPSS Ver. 25.0 and AMOS Ver. 26.0. The findings strongly supported predictive links among transformational leadership, self-efficacy in ESD teachers' attitudes toward ESD, and cooperative professional development. Therefore, findings provided greater insight into transformational leadership and ESD research and revealed mechanisms through which transformational leadership works in the ESD contexts. Finally, the major findings were discussed to encourage teachers to participate in cooperative professional development.
\end{abstract}

Keywords: Education for Sustainable Development (ESD); transformational leadership; teachers' self-efficacy in ESD; teachers' attitude toward ESD; cooperative professional development; structural equation modeling; phantom models approach

\section{Introduction}

Sustainable Development Goal 4 (SDG 4) emphasizes the transformation of education systems to promote the competencies that help citizens face our current challenges in the context of climate change and ecological crisis. Professional development provides continual learning and conscious reflection to respond effectively to change in professional practice, which implies that professional development can enhance quality education and help meet SDGs. It can be supported through informal or formal activities, such as accreditation schemes, in-service training, workshops, coaching, workplace projects, and professional learning community.

However, it has been reported that professional development is more effective when it is connected to the particular context of the institution or program, involves collaboration and cooperation among teachers, and is related to program objectives and student learning [1]. Based on findings [2-5], cooperative professional development (CPD) has been acknowledged as essential for facilitating teachers' competencies. CPD includes various activities such as peer observations, team teaching, research activities among colleagues, and a professional learning community (PLC), which are even considered for teachers to be a factor for successfully implementing the revised curriculum [6]. 
School principals' leadership style was paid special attention as an effective lever of CPD [7-13]. It has been reported that transformational leadership is more efficient than transactional leadership that does not strive for cultural change, favors top-down management, and is often silent on the manager's decision-making [14]. Similarly, it can be applied in the context of ESD [15-17]. Transformational principals can function as critical agents for creating the school vision in the framework of ESD, promoting practices that will facilitate ESD, and assisting teachers in developing deep competencies for ESD.

These can be activated better when principals discuss the necessity and significance of ESD together with teachers and allow teachers to be involved in decision-making. Pittman also [18] proposed participatory management structures as an integral element for sustainable development in an educational context, which implies transformational leadership that invites teachers to share decision-making authority. Korean schools have crafted and carried out their operation plan every year based on the National Curriculum and a particular school context. ESD was well-positioned as one of the cross-curricular themes in the 2015 revised National Curriculum [19]; however, the degree to which crosscurricular themes should be dealt with varies significantly, depending on circumstances facing schools and teachers' readiness or will. Therefore, transformative leadership is more highlighted to facilitate ESD in Korea.

Focusing on the promising role of principals' leadership, some researchers have revealed the effect of transformative leadership on CPD [7,20-25], along with the researchers' efforts to elucidate the effect of transformation leadership on teachers' self-efficacy [26-29] and teachers' attitudes [30]. It has been shown that teachers' self-efficacy and attitudes are major predictors of CPD [23-25]. Furthermore, it has been reported that teachers' self-efficacy mediates the relationship between transformative leadership and CPD [31-33], while a few studies have illustrated the effects of self-efficacy on attitudes [34-37].

Taken together with empirical evidence, there can be a gap in understanding the relationships of transformative leadership, teachers' self-efficacy, and CPD in a model. As an alternative, the model may include two mediators, self-efficacy and attitudes, in the relationship between transformational leadership and CPD. The inclusion of justifiable variables in the relationship between transformative leadership and CPD helps to elucidate the linkage between transformative leadership and CPD in ESD. Based on this relationship, the hypothetical model of principals' transformational leadership, teachers' self-efficacy in ESD, teachers' attitude toward ESD, and CPD can also be established. Exploring the underlying mechanisms through which transformational leadership stimulates CPD is the first step to precisely explain how transformational leaders produce positive outcomes such as CPD.

Moreover, these variables, such as teachers' self-efficacy and attitudes, are deemed to have a pivotal role for $\mathrm{CPD}$, suggesting a greater understanding of the relationship between transformational leadership and self-efficacy, attitudes, and CPD. Therefore, there is a need to examine empirically in the hypothetical model with two mediators of teachers self-efficacy in ESD, attitudes toward ESD, to explain better the relationships between transformational leadership and CPD in the context of ESD.

Nevertheless, while looking at the link between transformative leadership and CPD, there is still a dearth of studies on the mechanisms explaining how transformational leadership positively affects $\mathrm{CPD}$, focusing on this possible mechanism (transformative leadership-self-efficacy-attitudes-CPD). Furthermore, the hypothetical mechanism has also not gained much attention in the context of ESD; however, it still has to be highlighted. Therefore, the author considered the serial multiple mediation model to predict teachers' CPD in the context of ESD.

Thus, the author aimed to test a serial multiple mediation model with two mediators to explain the mechanism that underlies the relationship between principals' transformative leadership and CPD in the context of ESD, and to estimate and test specific mediation effects. Based on this purpose, the following research questions were addressed in this research. 
RQ1: Does transformational leadership positively influence CPD related to ESD directly or indirectly?

RQ2: Does teachers' self-efficacy in ESD mediate the relationship between transformational leadership and CPD?

RQ3: Do teachers' attitudes toward ESD mediate the relationship between transformational leadership and CPD?

RQ4: Do teachers' self-efficacy in ESD and their attitudes toward ESD mediate the relationship between transformational leadership and CPD in serial?

Unlike prior studies, which either investigated the effect of the variables mentioned above on each other separately [38] or focused on their relationships without considering ESD [8-13], this study tested the relationships of transformative leadership, teachers' self-efficacy, and CPD in a model. This approach is first in the context of ESD, to my knowledge, which will be able to make a significant contribution to the existing literature on transformational leadership, teachers' self-efficacy in ESD, teachers' attitudes toward ESD, and CPD.

\section{Literature Review}

\subsection{Transformational Leadership and ESD}

Principals are gaining attention as vital factors in the framework of ESD because they are in a position to shape the organizational conditions necessary for successful and sustained implementation, create the school vision, and set high expectations and explicit purposes [39-41]. Thus, researchers bring forward the roles of a principal as a transformational leader because transformational leadership can be considered a vital agent for building the school's organizational capacity and creating the cultural and structural conditions for meaningful and effective teaching and learning [42,43].

Transformational leadership is defined as a leadership approach that causes a change in individuals and social systems. Burns theorized that transformational and transactional leadership were mutually exclusive styles. Transactional leadership usually does not strive for organizational cultural change, while transformational leadership tries to change the organizational culture [14]. Recently, with growing interest in sharing decisionmaking authority, it has been approached as a dimension of transformational leadership. Pittman [18] proposes elements that are integral to success for sustainable development in an educational context. These include institutional commitment, shared vision of the future, participatory management structures, and external partnerships, which emphasize the need for shared decision-making authority and are related to transformational leadership [44].

With growing interest in the significance of transformational leadership in the educational setting, researchers have analyzed relations among transformational leadership, teachers' efficacy, teachers' attitudes, and teachers' participation in CPD. The relationships among variables were discussed more specifically in the following section, based on the related literature and empirical evidence.

\subsection{Relationship between Transformational Leadership and Teachers' CPD}

As a step toward constructing a conceptual framework for the study, the researcher reviewed the extensive research on teachers' participation in cooperative professional development (CPD). CPD is defined as any activity in which two or more teachers work together for their professional growth, and Glatthorn [45] used cooperative professional development (CPD) as an inclusive term to embrace forms of peer-oriented systems. Recently, transformational leadership has been acknowledged as an essential factor in facilitating CPD [16-18]. Furthermore, the findings have shown a relationship between a leader's transformational leadership and CPD [8-12,20-25]. Therefore, considering this evidence, it is likely that transformational leadership will impact teachers' CPD in the context of ESD either directly or indirectly. Thus, the following hypothesis (H1) was established. 
Hypothesis 1 (H1). Transformational leadership will have a positive effect on teachers' CPD directly or indirectly.

Hypothesis one requires testing of both direct and indirect effects. Thus, two subhypotheses were established: a hypothesis on the direct effect (H1a) and the indirect effect (H1b). Hypothesis one can be considered to be rejected when both hypotheses are not accepted.

Hypothesis 1a (H1a): Transformational leadership will have a positive effect on teachers' CPD directly. Hypothesis $\mathbf{1 b}$ (H1b): Transformational leadership will have a positive effect on teachers' CPD indirectly.

\subsection{Relationship among Transformative Leadership, Teachers' Efficacy, and CPD}

Transformational principals can foster individual accountability in implementing ESD, provide teachers with vicarious experiences by demonstrating good models for implementing ESD, and facilitate teachers to master knowledge and skills in ESD. As a result, teachers' efficacy can be strengthened. Research findings have reported empirical evidence that transformational leadership has significantly positive effects on teachers' self-efficacy [26-29,34-37].

Guthrie and Schwoerer [46] proposed that individuals with higher self-efficacy levels are most likely to have positive attitudes toward learning, a belief that there are benefits to be gained from participation in such activities, and a greater awareness of their specific development needs. Prior research has reported that teachers with high self-efficacy are more likely to participate in professional development than those with lower selfefficacy [47]. Similarly, Lohman [48] also reported that teachers' self-efficacy is one of the most critical factors affecting teachers' participation in learning activities. In a study of the factors that influence teachers' participation in CPD, their self-efficacy has a significant effect on teachers' CPD [23-25].

Taking together the evidence, transformational leadership will affect teachers' selfefficacy in ESD, and teachers' self-efficacy will influence teachers' CPD. Also, considering H1, it is highly likely that self-efficacy will mediate the relationship between transformative leadership and teachers' CPD. Therefore, the author established the following hypotheses based on the relationship among transformative leadership, teachers' self-efficacy, and CPD.

Hypothesis 2 (H2). Transformational leadership will affect teachers' self-efficacy in ESD.

Hypothesis 3 (H3). Teachers' self-efficacy will affect teachers' CPD in ESD.

Hypothesis 4 (H4). Teachers' self-efficacy in ESD will mediate the relationship between transformational leadership and CPD.

\subsection{Relationship among Transformative Leadership, Attitude, and CPD}

Many researchers emphasize the importance of attitudes toward ESD [49-52]. Developing a positive attitude towards sustainability might promote engagement with ESD [53]. Furthermore, teachers' perceptions of ESD's importance play a significant role in their attitudes towards ESD and their willingness to learn about the subject [52]. Empirical evidence has shown that transformational leadership significantly affects teachers' attitudes [54-56]. Heystek and Terhoven [57] explain that teachers' participation in CPD can be motivated by needs such as increased teacher awareness, updating of teacher knowledge, and adoption of new teaching practices. According to Amos and Benton [58], teachers attitudes affect CPD.

Empirical evidence suggests that it is likely that transformational leadership will affect teachers' attitudes toward ESD, and positive attitudes toward ESD affect participation in CPD related to ESD. Furthermore, teachers' attitudes will probably also mediate the relationship between transformative leadership and CPD. Therefore, the following 
hypotheses were established based on the relationship among transformative leadership, teachers' attitudes, and CPD.

Hypothesis 5 (H5). Transformational leadership will affect teachers' attitudes toward ESD.

Hypothesis 6 (H6). Teachers' attitudes toward ESD will influence CPD.

Hypothesis 7 (H7). Teachers' attitudes toward ESD will mediate the relationship between transformational leadership and CPD.

\subsection{Transformative Leadership, Teachers' Self-Efficacy, Attitude, and CPD}

The findings have revealed a positive relationship between teachers' self-efficacy and positive attitudes towards inclusion [57,59-63]. For example, Wiesel and Dror [60] stated that Israeli primary school teachers with higher self-efficacy levels had a more positive attitude towards inclusion applications. Lee and Krapfl [64] also corroborated the significance of self-efficacy in science teaching, identifying a link between teachers self-efficacy in teaching science and their attitudes toward science. Similarly, teachers' positive attitudes are related to firm self-efficacy beliefs in the ESD field also. Gan and Gal [38] found that a pre-service teacher with high self-efficacy for promoting ESD exhibited positive attitudes towards the environment and pro-environmental behaviors in the private and public spheres. Thus, teachers' self-efficacy based on teachers' mastery can influence teachers' attitudes. It implies that when the teachers believe in their competency to perform their tasks successfully, they likely perceive ESD to be more valuable than the teachers with low self-efficacy, which in turn, may affect CPD related to ESD.

Considering theoretical evidence and above hypotheses (H1, H2, H3) conjointly, it is highly probable that transformational leadership influences teachers' self-efficacy (M1), which, in turn, affects teachers' attitudes (M2), resulting in teachers' CPD. In this process, teachers' self-efficacy is likely to mediate the relationship between transformational leadership and attitudes. Teachers' attitudes may also mediate the relationship between teachers' self-efficacy and CPD. Therefore, the following hypotheses were established.

Hypothesis 8 (H8). Teachers' self-efficacy in ESD will affect teachers' attitudes toward ESD.

Hypothesis 9 (H9). Teachers' self-efficacy in ESD will mediate the relationship between transformational leadership and teachers' attitudes toward ESD.

Hypothesis 10 (H10). Teachers' attitudes toward ESD will mediate the relationship between teachers' self-efficacy in ESD and CPD.

Hypothesis 11 (H11). Teachers' self-efficacy in ESD and teachers' attitudes toward ESD will mediate the relationship between transformational leadership and CPD in serial.

\section{Methods}

\subsection{Data Collecting and Sampling Procedures}

The data was collected from September 10, 2018, to October 10, 2018. The convenience sampling method was preferred, and 211 teachers from various teaching fields responded to the survey. All missing data were deleted, and 203 cases were qualified for analysis. The demographics of the sample are displayed in Table 1.

\subsection{Research Variables and Measurement Instrument}

There is an independent variable (principals' transformational leadership: TL) and a dependent variable (teachers' cooperative professional development: CPD), and two mediators [(teachers' self-efficacy in the ESD: TSE), (teachers' attitudes toward ESD: AT)] so that the researcher can test hypotheses. The measurement instruments were a questionnaire. Items using a Likert scale ranging from one to four points were used for this study. Items for measuring each scale were primarily adopted from previous studies [65-68] that reported 
high statistical reliability and validity, but the author applied modifications to fit this study.

Table 1. Sample demographics.

\begin{tabular}{|c|c|c|c|c|c|}
\hline \multirow{2}{*}{ Gender } & Male & 31.6 & \multirow{5}{*}{$\begin{array}{l}\text { Year(s) of teaching } \\
\text { experience }\end{array}$} & $0<$ Years $<5$ & 30.1 \\
\hline & Female & 68.4 & & $5 \leq$ Years $<10$ & 18.7 \\
\hline \multirow{5}{*}{ Age } & $20 \mathrm{~s}$ & 16.1 & & $10 \leq$ Years $<15$ & 15.5 \\
\hline & $30 \mathrm{~s}$ & 39.4 & & $15 \leq$ Years $<20$ & 12.4 \\
\hline & $40 \mathrm{~s}$ & 22.7 & & $20 \leq$ Years & 23.3 \\
\hline & $50 \mathrm{~s}$ & 19.7 & \multirow{5}{*}{$\begin{array}{l}\text { Year(s) working with the } \\
\text { principal at this school }\end{array}$} & Year $<1$ & 31.6 \\
\hline & $60 \mathrm{~s}$ & 2.1 & & $1 \leq$ Year $<2$ & 36.3 \\
\hline \multirow{3}{*}{ School's location } & Large City & 59.6 & & $2 \leq$ Years $<3$ & 19.7 \\
\hline & City & 23.8 & & $3 \leq$ Years $<4$ & 4.1 \\
\hline & Village or Rural area & 26.6 & & $4 \leq$ Years & 8.3 \\
\hline \multirow{3}{*}{$\begin{array}{l}\text { Grade level of } \\
\text { students I teaching }\end{array}$} & Elementary (1-6) & 27.4 & \multirow{3}{*}{ Highest educational level } & Bachelor & 75.1 \\
\hline & Middle (7-9) & 18.2 & & Master & 23.8 \\
\hline & High (10-12) & 54.4 & & Doctor & 1.1 \\
\hline
\end{tabular}

\subsubsection{Transformational Leadership}

Transformational leadership scale adapted from "KEDI comprehensive tests" were developed by Park and colleagues in the Korean language [67]. The original items are measured on a five-point Likert scale ranging from 1 to 5 ; ' 1 ' for strongly disagree, ' 2 ' for disagree, ' 3 ' for undecided, ' 4 ' for agree, and ' 5 ' for strongly agree. However, the author transformed it into a four-point Likert scale ranging from 1 to 4 : ' 1 ' for strongly disagree, ' 2 ' for disagree, ' 3 ' for agree, and ' 4 ' for strongly agree.

Transformational leadership in education have been approached as a multidimensional construct that includes sub-dimensions: building school vision (developing a shared vision); establishing school goals; providing intellectual stimulation; offering individualized support; modeling best practices and essential organizational values; demonstrating high-performance expectations; creating a productive school culture; developing structures to foster participation in school decisions; managing the instructional program [20]. Considering the role of transformational leadership in ESD and prior research on transformational leadership, the author focused on sharing decision-making authority, intellectual stimulation, providing instructional support, and building curriculum expertise.

In this study, the transformational leadership scale consisted of 9 items measuring three dimensions: sharing decision-making authority (S), coordinating the curriculum and instructional support (C), and intellectual stimulation (I), along three sub-scales each including three items: 'S' (e.g., principal (s) in this school ensure that teachers have adequate involvement in decisions); ' $\mathrm{C}$ ' (e.g., principal (s) in this school have a philosophy and expertise in curriculum development), and ' $\mathrm{I}$ ' (e.g., principal (s) in this school supports teachers to participate in professional development).

All the scale items were subjected to a bivariate correlation matrix and exploratory factor analysis (EFA) applying principal axis factoring technique with Varimax rotation. Item with communality less than 0.50 or item with a loading less than 0.50 on component was removed. Kaiser-Meyer-Olkin (KMO) test allows the researcher to measure sampling adequacy, and Bartlett's Test of Sphericity enable the researcher to test the presence of correlations among variable. In this research, both of them were carried out. The bivariate correlation analysis confirmed that none of the pairs of variables with bivariate correlation scores were greater than 0.6. EFA for transformational leadership led to a solution comprising three factors, as shown in Table 2. 
Table 2. Factors loadings from Principal Axis Factoring technique with Varimax rotation.

\begin{tabular}{|c|c|c|c|}
\hline Item & $\mathbf{S}$ & $\mathrm{C}$ & $\mathbf{I}$ \\
\hline Ensures that teachers have adequate involvement in decisions & 0.87 & 0.23 & 0.12 \\
\hline Empowers teachers to perform autonomous tasks & 0.83 & 0.19 & 0.33 \\
\hline Frequently discusses educational issues with teachers & 0.74 & 0.31 & 0.20 \\
\hline Has a philosophy and expertise in curriculum development & 0.28 & 0.85 & 0.22 \\
\hline Analyzes the problems in the curriculum and presents solutions & 0.18 & 0.85 & 0.22 \\
\hline Gives support to help you improve teaching practices & 0.41 & 0.69 & 0.32 \\
\hline Supports teachers to participate in professional development & 0.12 & 0.11 & 0.87 \\
\hline Encourages teachers' collaboration for their professional growth & 0.32 & 0.30 & 0.72 \\
\hline Encourages teachers' classes observation and providing feedback & 0.24 & 0.38 & 0.69 \\
\hline Eigen Value & 2.44 & 2.37 & 2.12 \\
\hline Percentage of variance explained & 27.11 & 26.32 & 23.52 \\
\hline Cronbach's $\alpha$ & 0.87 & 0.85 & 0.80 \\
\hline
\end{tabular}

Note. 'S': Sharing decision-making authority, 'C': Coordinating the curriculum and instructional support, 'I': Intellectual stimulation.

Kaiser-Mayer-Olkin Measure of Sampling Adequacy was 0.92, which indicates the sampling is adequate. Also, Bartlett's Test of Sphericity was significant by 0.000 . As shown in Table 3, a total of three constructs were extracted with eigenvalues exceeding 1.0, each having factor loadings greater than 0.50 on three items. The three extracted factors collectively accounted for $76.95 \%$ of the total variance in the data.

Table 3. Variables and Measurement Instrument.

\begin{tabular}{|c|c|c|}
\hline Variables & Items & 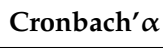 \\
\hline CPD & $\begin{array}{l}\text { How often do you do the following activities for the last } 12 \text { months in an ESD context? } \\
\text { Teach jointly as a team in the same class } \\
\text { Observe other teachers' classes and provide feedback } \\
\text { Engage in joint activities across various groups } \\
\text { Exchange teaching materials with colleagues } \\
\text { Take part in a professional learning community }\end{array}$ & 0.92 \\
\hline $\mathrm{TL}$ & $\begin{array}{l}\text { How strongly do you agree with the following statements about the principal in this school? } \\
\text { Ensures that teachers have adequate involvement in decisions } \\
\text { Empowers teachers to perform autonomous tasks } \\
\text { Frequently discusses educational issues with teachers } \\
\text { Has a philosophy and expertise in curriculum development } \\
\text { Analyzes the problems in the curriculum and presents solutions } \\
\text { Gives support to help you improve teaching practices } \\
\text { Supports teachers to participate in professional development } \\
\text { Encourages teachers' collaboration for their professional growth } \\
\text { Encourages teachers' classes observation and providing feedback }\end{array}$ & 0.79 \\
\hline TSE & $\begin{array}{c}\text { To what extent can you do the following in the context of ESD? } \\
\text { I can successfully implement ESD } \\
\text { I can incorporate SD into my academic field } \\
\text { I can successfully teach all relevant subject content } \\
\text { I can use appropriate teaching methods } \\
\text { I can apply valid assessment tools to evaluate my students } \\
\text { I can motivate students to participate in learning activities } \\
\text { I can address students' learning needs. } \\
\text { I can improve my teaching competency as time goes by. }\end{array}$ & 0.93 \\
\hline AT & $\begin{array}{l}\text { How strongly do you agree with the following statements? } \\
\text { ESD improves students' future decision-making skills } \\
\text { ESD improves students' critical thinking skills } \\
\text { ESD helps students to solve various global problems } \\
\text { ESD helps students to solve various local problems }\end{array}$ & 0.83 \\
\hline
\end{tabular}

Note. CPD: Cooperative Professional Development TL: Transformational Leadership, TSE: Teachers' Self-Efficacy in ESD, AT: Teachers' Attitudes Toward ESD. All items were measured on a four-point Likert scale. 


\subsubsection{Teachers' Self-Efficacy in ESD}

A teacher's self-efficacy is drawn from the interaction of behavior, individual characteristics, and environmental contexts [47], which implies that self-efficacy is situation-specific and must be subjected to change as the context varies. Thus, these three factors can be analogous to the legs of a tripod. In other words, without one, the others cannot stand. Eventually, when one is altered, the others must shift as well. Regarding the self-efficacy scale, the Teachers Sense of Efficacy Scale developed by Tschannen-Moran and WoolfolkHoy [66] plays a critical role in conceptualizing and applying teacher efficacy. However, it has not considered the context of ESD in Korea, and it has to be modified to fit in the context of ESD to investigate teachers' self-efficacy in ESD. An ideal measure of self-efficacy in ESD includes items directly related to the context of implementing ESD as cross-curricular (e.g., I can incorporate SD into my academic field). All items in the scales were measured on a four-point scale, with response categories of ' 1 ' for strongly disagree, ' 2 ' for disagree, ' 3 ' for agree, and ' 4 ' for strongly agree. Therefore, a scale titled Teacher Self-Efficacy in ESD was designed in this study, which did not replicate the Teachers' Sense of Efficacy Scale (short form), but modified it to reflect the nature of ESD. Teachers' Self-efficacy in ESD was assessed with eight items to cover the two subscales: self-efficacy in ESD instruction and student engagement in ESD. However, these were not reproduced through exploratory factor analysis; instead, exploratory factor analysis extracted a single factor, accounting for $67.0 \%$ of the variance.

\subsubsection{Teachers' Attitudes toward ESD}

Four items were adopted from the scale entitled Beliefs on Education for Development (e.g., ESD improves students' future decision-making skills). It was developed by Sagdıc and Sahin [65] and is measured on a five-point Likert scale ranging from 1 to 5 ; ' 1 ' for strongly disagree, ' 2 ' for disagree, ' 3 ' for undecided, ' 4 ' for agree, and ' 5 ' for strongly agree. However, the author transformed it into a four-point Likert scale ranging from 1 to 4 : ' 1 ' for strongly disagree, ' 2 ' for disagree, ' 3 ' for agree, and ' 4 ' for strongly agree. Exploratory factor analysis for Teachers' Attitudes Toward ESD yielded a single factor, accounting for $66 \%$ of the variance.

\subsubsection{Cooperative Professional Development}

Five items measured the Cooperative Professional Development scale (e.g., teach jointly as a team in the same class), which was adapted from the 2013 Teaching and Learning International Study (TALIS) developed by the Organization for Economic Cooperation and Development (OECD) [68]. The question was adapted to be connected to ESD, such as, how often do you do the following activities for the last 12 months in ESD context? All items in the scales were measured on a four-point scale, with response categories of ' 1 ' for never, ' 2 ' for once a year or less, ' 3 ' for 2-4 times a year, and ' 4 ' for 5-10 times a year. Exploratory factor analysis for CPD produced a single factor, accounting for $80.0 \%$ of the variance. All items based on the abroad scale were translated more carefully into the Korean language. Table 3 lists variables, the scale items, and Cronbach' $\alpha$.

As shown in Table 3, all constructs exhibited Cronbach's $\alpha$ reliability coefficient values greater than 0.70 . Thus, the internal consistency of each construct indicates high internal consistency reliability

\subsection{Analysis Method: Structural Equation Modeling and Phantom Model Approach}

This study focused on testing a hypothetical model with two mediators and serial multi-mediator and estimating and testing indirect effects to explain the mechanism underlying the relationship between transformational leadership and CPD in the ESD. In this respect, the author used structural equation modeling (SEM) that allows a researcher to manage measurement error, with its strength to test hypotheses based on complex relationships among variables. The SEM procedure consists of two phases. 
As a first step, the measurement model was performed using confirmatory factor analysis (CFA) to assess the extent to which each of the latent variables was represented by its indicators. Above all, the fit of the measurement model was analyzed using various fit indices, and then, validity for each construct was evaluated for measurement scales. As for fit indices, ratio of $\chi^{2} / \mathrm{df}$ and RMSEA (root mean square error of approximation), as well as CFI (Comparative fit index) and TLI (Tucker-Lewis index), which are relatively unaffected by sample size and performs well even when the sample size is small, were applied in this study [69]. A rule for their acceptance has applied the threshold that researchers generally recommend [69-71], as shown in Table 3. The construct validity for each construct was tested using two criteria: CR (composite reliability) and AVE (average variance extracted) indices. When generally CR is more than 0.7 , and AVE is more than 0.5 , they are considered acceptable [72,73]. In addition, Cronbach's alpha was measured to test internal consistency. Cronbach's alpha coefficient of 0.70 and above is considered to be good.

As the second step, the structural model analysis was performed to measure the fit and path coefficients of the hypothesized structural model. Unfortunately, the default bootstrap procedure provided by AMOS only provides bootstrapping of the total indirect effect. It does not typically offer bootstrap point estimates and confidence bounds for specific indirect effects. Given these practical weaknesses, the author estimated and tested each of the indirect effects by applying a phantom model approach that allows the researcher to test the specific indirect effects.

The phantom model works by respecifying the specific indirect effects of the covariance structure model as the total effect in an independent phantom model, based on bootstrap procedures which have been considered more powerful for detecting indirect effects [74]. The indirect effect can become non-normal data when related to the product indicator and product effect even though the data was initially normally distributed. Bias corrected confidence interval (BCCI) minimizes problems that can arise from non-normal sampling [75] and is considered to be a persuasive approach to testing the mediation effects when an indirect effect exists [76,77]. Therefore, the phantom model approach has strength for testing specific indirect effects because it can engender bootstrap point estimates, SEs, or confidence limits for specific indirect effects in an SEM program with a bootstrap utility [74]. The data were analyzed using SPSS 25.0 and AMOS 26.0.

\subsection{Model Construction}

Taking together the above hypothesis and the theoretical discussions, the author constructed a hypothesized structural equation model, consisting of the measurement model and structural model, and phantom models representing the specific indirect effects of the covariance structure model as the total effect in the independent model. Figure 1 shows hypothesized structural equation model and the phantom models.

As shown in Figure 1, the author used a second-order model for transformational leadership (TL), considering a construct loading into three distinct components in the exploratory factor analysis. Furthermore, this study focused on the effect of TL on CPD, not the impact of sub-constructs on CPD, and the second-order model is more parsimonious and interpretable. In Figure 1, there is the five phantom model with the specific indirect effect modeled as a total effect: Phantom model I: effects of transformative leadership on teachers' CPD through teachers' self-efficacy, Phantom model II: effects of transformative leadership on teachers' CPD through attitudes toward ESD, Phantom model III: effects of transformative leadership on teachers' CPD through teachers' self-efficacy in ESD and teachers' attitudes toward ESD in serial, Phantom model IV: effects of transformative leadership on teachers' attitudes through teachers' self-efficacy in ESD, and Phantom model V: effects of teachers' self-efficacy in ESD on teachers' CPD through teachers' attitudes. The author assigned equality constraints between the path coefficients of the phantom model and the path coefficients implicated in the specific indirect effect in the structural equation model. For example, the author created the Phantom model, consisting of two phantom variables (P1, P2) and two direct paths. Then, equality constraints, denoted as a and b 
for the paths from transformative leadership to teachers' self-efficacy and from teachers' self-efficacy to teachers' CPD, respectively, are imposed between the implicated path coefficients in both the structural equation model and Phantom model I.

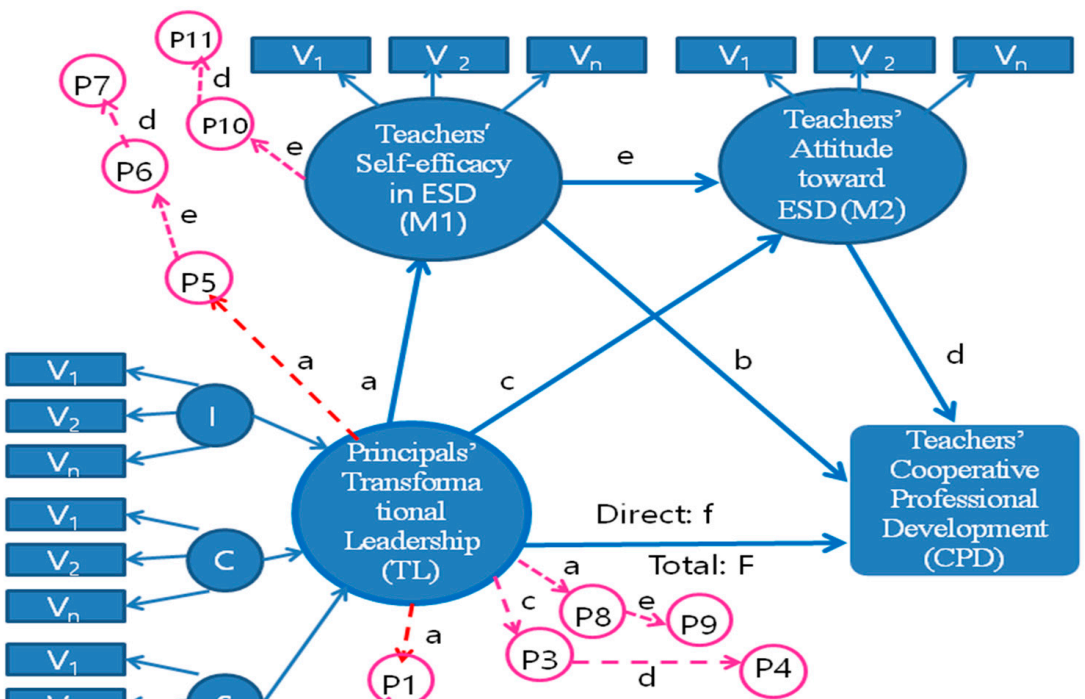

Red dot line arrows indicate phantom models.

$\checkmark$ indicates observable indicators for each construct.

Figure 1. Hypothesized Structural Equation Model and Phantom Models.

\section{Results}

\subsection{Measurement Model Test through Confirmatory Factor Analysis}

As a step of SEM, the author carried out the measurement model test to assess the reliability and validity of the observed variables concerning the latent variable using confirmatory factor analysis. Table 4 shows the fit indices for measurement models, the AVEs, and the CRs for each construct.

Table 4. Measurement Model Test.

\begin{tabular}{ccccc}
\hline & General Rule & TL & TSE & AT \\
\hline Ratio of $\chi^{2} / \mathrm{df}$ & $\leq 2$ or 3 & 2.04 & 2.31 & 2.87 \\
\hline TLI & $\geq 0.95$ & 0.96 & 0.98 & 0.91 \\
\hline CFI: & $\geq 0.95$ & 0.97 & 0.98 & 0.92 \\
\hline RMSEA & $<0.06-0.08$ & 0.07 & 0.07 & 0.07 \\
\hline CR & $\geq 0.7$ & 0.89 & 0.93 & 0.82 \\
\hline AVE & $\geq 0.5$ & 0.72 & 0.62 & 0.54 \\
\hline
\end{tabular}

Note. TL: Transformational Leadership, TSE: Teachers' Self-Efficacy in ESD, AT: Teachers' Attitudes Toward ESD.

As shown in Table 4, the estimates of the overall goodness-of-fit criteria met their acceptable level, respectively, which confirmed that the measurement model exhibited a pretty good fit with the data and all the indicators loaded significantly on their corresponding factors. Overall, the confirmatory factor model reflected a good fit to the data. Also, the AVEs for all constructs were between 0.54 and 0.72 . In addition, the CRs for all constructs were between 0.80 and 0.93 , providing empirical evidence of acceptable item convergence on the constructs and showing evidence of convergent validity. Therefore, the construct validity of the measurement scales was sufficiently high. Generally, CFI values greater than 0.95 are recommended [69-71]; however, CFI values greater than 0.90 are considered to be a reasonably satisfactory fit [78-80]. Therefore CFI for AT may indicate a reasonably good fit of the model 


\subsection{Structural Model Test}

Figure 2 and Table 5 depict the structural model analysis results, including the path coefficient significance and the model fit indices.

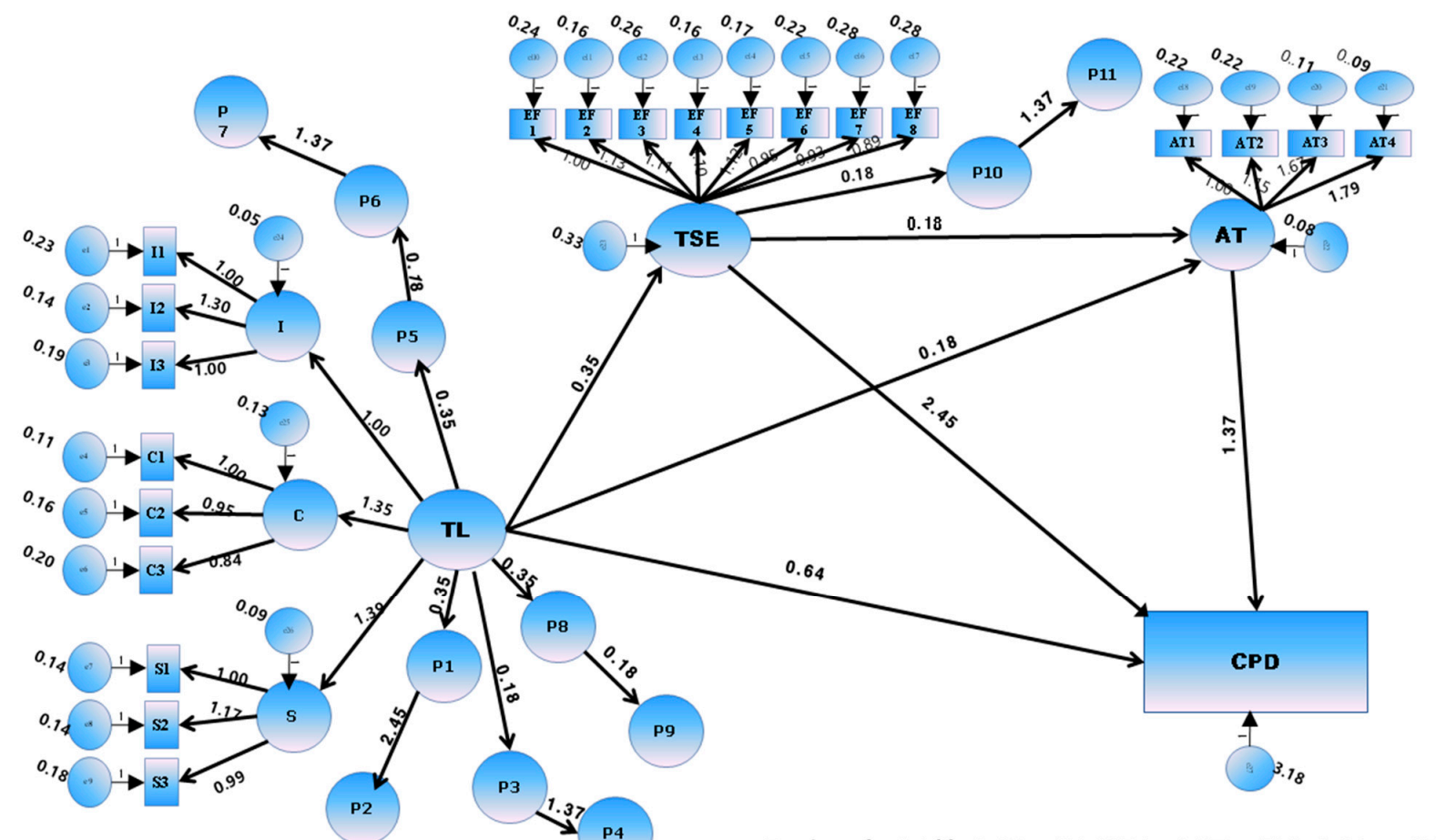

Ratio of $\chi 2 / d f: 2.12$ RMSEA: 0.07 TLI: 0.91 CFI: 0.91

Figure 2. Structural Equation Model and Phantom Models showing relationships between Transformational Leadership and Cooperative Professional Development.

Table 5. Path Coefficients for Direct Effects.

\begin{tabular}{ccccccc}
\hline Hypothesis & Path & B & Beta & SE & $p$ & Decision \\
\hline H1a & TL $\rightarrow$ CPD & 0.64 & 0.10 & 0.42 & 0.129 & Reject \\
\hline H2 & TL $\rightarrow$ TSE & 0.35 & 0.22 & 0.14 & 0.010 & Support \\
\hline H3 & TSE $\rightarrow$ CPD & 2.45 & 0.58 & 0.30 & 0.001 & Support \\
\hline H5 & TL $\rightarrow$ AT & 0.18 & 0.21 & 0.07 & 0.015 & Support \\
\hline H6 & AT $\rightarrow$ CPD & 1.37 & 0.17 & 0.54 & 0.011 & Support \\
\hline H8 & TSE $\rightarrow$ AT & 0.18 & 0.34 & 0.05 & 0.001 & Support \\
\hline
\end{tabular}

Note. CPD: Cooperative Professional Development TL: Transformational Leadership, TSE: Teachers' Self-Efficacy in ESD, AT: Teachers' Attitudes Toward ESD.

As shown in Figure 2, the overall model fit statistics indicate that hypothesized model provides a good fit to the data ( $\chi^{2} / \mathrm{df}: 2.12$, CFI: 0.91, RMSEA: 0.07). Generally, for TLI and CFI, values greater than 0.95 are considered to be a good fit [70]. However, TLI values greater than $0.90[79,81]$ and CFI values greater than 0.90 [78-80] are considered a satisfactory fit. All of TLI and CFI for the hypothesized model can indicate a reasonably satisfactory fit of the model.

As shown in Table 5, transformational leadership has no significantly direct effect on CPD, which means that the direct effect of transformational leadership on CPD (H1a) was rejected. However, Table 5 depicts that the empirical results confirmed that five paths except for the direct effect of TL on CPD were at a statistically significant level. More specifically, TSE (B: 2.45, $p<0.01$ ) and AT (B: 1.37, $p<0.05$ ) were significant determinants of CPD. TL (B: 0.35, $p<0.05$; B: 0.18, $p<0.05$ ) has an effect on TSE and AT, respectively, 
and TSE (B: $0.18, p<0.001$ ) statistically significantly influences AT. Therefore, hypotheses predicting direct effects between variables $(\mathrm{H} 2, \mathrm{H} 3, \mathrm{H} 5, \mathrm{H} 6$, and $\mathrm{H} 8)$ are not rejected.

The bootstrap procedure was used to examine the significance levels of indirect effects for the hypothesized model. Table 6 shows the bootstrap estimates of the total indirect and the specific indirect effects of transformative leadership on teachers' CPD, with $95 \%$ confidence bounds, based on 2000 resample.

Table 6. Bootstrap estimates of Indirect Effects.

\begin{tabular}{cccccccc}
\hline \multirow{2}{*}{ Hypothesis } & Path & B & SE & $p$ & \multicolumn{2}{c}{ 95\% Confidence Interval } \\
\cline { 6 - 8 } & & & & Lower Bound & UpperBound & Decision \\
\hline $\mathrm{H} 4$ & $\mathrm{TL} \rightarrow \mathrm{TSE} \rightarrow \mathrm{CPD}$ & 0.85 & 0.35 & 0.000 & 0.42 & 1.05 & Support \\
\hline $\mathrm{H} 7$ & $\mathrm{TL} \rightarrow \mathrm{AT} \rightarrow \mathrm{CPD}$ & 0.25 & 0.04 & 0.000 & 0.15 & 0.33 & Support \\
\hline $\mathrm{H} 9$ & $\mathrm{TL} \rightarrow \mathrm{TSE} \rightarrow \mathrm{AT}$ & 0.06 & 0.03 & 0.002 & 0.01 & 0.16 & Support \\
\hline $\mathrm{H} 10$ & $\mathrm{TSE} \rightarrow \mathrm{AT} \rightarrow \mathrm{CPD}$ & 0.25 & 0.09 & 0.000 & 0.07 & 0.45 & Support \\
\hline $\mathrm{H} 11$ & $\mathrm{TL} \rightarrow \mathrm{TSE} \rightarrow \mathrm{AT} \rightarrow \mathrm{CPD}$ & 0.09 & 0.01 & 0.000 & 0.03 & Support \\
\hline
\end{tabular}

Note. CPD: Cooperative Professional Development TL: Transformational Leadership, TSE: Teachers' Self-Efficacy in ESD, AT: Teachers' Attitudes Toward ESD.

As seen in Table 6, in line with hypotheses, the indirect effect of the transformative leadership on teachers' CPD through teachers' self-efficacy in ESD (H4) is statistically significant (B: $0.85,95 \%$ CI $[0.42,1.05]$ ) and indirect effect of the transformative leadership on teachers' CPD through teachers' attitudes toward ESD (H7) is also statistically significant (B: $0.25,95 \%$ CI $[0.15,0.33])$. Furthermore, the indirect effect of the transformative leadership on teachers' attitudes toward ESD through teachers' self-efficacy in ESD (H9) is statistically significant (B: $0.06,95 \%$ CI $[0.01,0.16]$ ) and indirect effect of the teachers' self-efficacy in ESD on teachers' CPD through teachers' attitudes toward ESD (H10) is also statistically significant (B: $0.25,95 \%$ CI $[0.07,0.45]$ ). Moreover, the indirect effect of the transformative leadership on teachers' CPD through teachers' self-efficacy in ESD and teachers' attitudes toward ESD in serial (H11) is also statistically significant (B: 0.09, 95\% $\mathrm{CI}[0.03,0.18])$. Hence, all hypotheses predicting the indirect effects ( $\mathrm{H} 4, \mathrm{H} 7, \mathrm{H} 9, \mathrm{H} 10$, and H11) are supported, implying that transformational leadership has a significantly positive effect on CPD indirectly (HI-2). Furthermore, taking together H1a (direct effect) and H1b (indirect effect), despite the rejection of the direct effect (H1a), support of H1b implies that $\mathrm{H} 1$ can be accepted. Therefore, it is concluded that transformational leadership has a positive effect on CPD through indirect paths.

\section{Conclusions}

The process of how transformational leadership exerts its influence has become a growing source of interest. However, there is still a lack of research on the mechanisms explaining how transformational leadership positively exerts CPD in research on the effect of transformational leadership on CPD. Hence, this study aimed to provide empirical evidence that may help in explaining the mechanism through which transformative leadership affects CPD. To this end, the author proposed a serial multiple mediation model that incorporates self-efficacy and attitudes as an underlying mechanism that explains the positive impact transformational leaders have on CPD related to ESD. In addition, the author analyzed specific indirect effects in the relationship of principals' transformational leadership on CPD using the phantom model approach modeling the specific indirect effects in the hypothetical model. The findings strongly supported predictive links among transformational leadership, self-efficacy in ESD teachers' attitudes toward ESD, and CPD. Therefore, these findings provide greater insight into transformational leadership and ESD research and reveal mechanisms through which transformational leadership works in ESD contexts. 


\subsection{Discussion}

This study can be discussed in terms of the result findings. First, the effects of transformative leadership on CPD were also confirmed in ESD contexts. This finding supported several prior studies [7-11], asserting the significant role of transformational leadership in teachers' CPD. Therefore, these findings confirmed that transformational leadership is appropriate for making teachers more engaged in $\mathrm{CPD}$, which implies that principals can make a difference in teachers' $\mathrm{CPD}$.

Second, teachers' self-efficacy and attitudes, relatively stable traits, were confirmed to predict CPD related to ESD. Also, it is confirmed that transformational leadership can change teachers' self-efficacy and attitudes towards a positive direction. Therefore, transformational leadership could be a powerful strategy to boost teachers' self-efficacy and thus to form positive teachers' attitudes toward ESD. Also, this result supports prior research exploring the effect of self-efficacy on CPD [26-29], and is in line with the results of previous studies showing the effect of attitudes on CPD [58].

Third, the findings demonstrated that teachers' self-efficacy is a significant predictor of attitude toward ESD. The findings are consistent with Gan and Gal's [60] result findings. Revealing the relationship between teachers' self-efficacy and their attitudes toward ESD will help researchers and teachers make inferences regarding future studies that may help develop positive attitudes towards ESD. Furthermore, this result highlights that sources of self-efficacy in ESD are used as a strategy to develop teachers' positive attitudes toward ESD because self-efficacy is one of the key determinants of teachers' attitudes toward ESD.

Furthermore, as assumed in the research model, findings showed that the influence of transformational leadership on CPD depends on the interplay of high self-efficacy in ESD and positive teachers' attitudes toward ESD. These findings strongly supported predictive links among transformational leadership, self-efficacy in ESD teachers' attitudes toward ESD, and CPD. To date, no research has investigated the relationship between transformational leadership, teachers' self-efficacy, teachers' attitudes toward ESD, and $\mathrm{CPD}$ related to ESD, to my knowledge. However, these findings can contribute to some progress in this field because this study investigated transformational leadership, selfefficacy in ESD, and teachers' attitudes toward ESD simultaneously as predictors of CPD in the context of ESD, applying a structural equation model.

\subsection{Implications}

This study presents several key findings and has some practical implications for principals, policy-makers, teachers, and researchers regarding teachers' CPD, practically and theoretically. Above all, as this research showed the indirect effects of transformational leadership on CPD through self-efficacy in ESD and teachers' attitudes toward ESD, the principals must be aware of all possible causal-chain relationships between transformational leadership and CPD. This causal relation is a challenge for school principals. However, considering CPD's role in achieving SDGs, the principal must allow teachers to participate in decision-making, promote instructional support, and provide intellectual stimulation. Thus, the author suggests that educational institutions provide proper professional development programs for principal to increase transformational leadership, and principals also have to do their best to improve their transformational leadership.

In addition to practical implications, this study resulted in some progress in ESD field research. These findings help clarify the nature of the relationship between the principals' transformational leadership and CPD and facilitate a better understanding of the relationship between the principals' transformational leadership and CPD. Regarding research methodology, specific mediating effects were analyzed using the phantom analysis method, which is still somewhat unfamiliar and innovative in ESD field research. The analysis process of this study may be helpful when researchers try to analyze specific mediating effects using AMOS

Unlike prior studies, which either investigated the effect of the variables mentioned above on each other separately [38] or focused on their relationships without considering 
ESD [8-13], this study tested the research hypotheses and conceptual model. As a result, this research made a significant contribution to the existing literature on transformational leadership, self-efficacy in ESD, teachers' attitudes toward ESD, and CPD.

\subsection{Limitations and Recommendations for Future Research}

This study makes some noteworthy contributions to the existing literature, clarifying the mechanism underlying the relationship between principal transformational leadership practices, teachers' ESD efficacy and teachers' attitude toward ESD, and CPD through the Phantom model approach, a novel approach in the field of ESD. However, limitations must be considered. First of all, non-probability convenience sampling was chosen as the sampling method in this study. Therefore, the results of this study might not be generalized to the whole of Korean secondary in-service teachers. Furthermore, in addition to the limitations of sampling, specific themes need to be explored further.

Second, this study did not analyze the relationship between the sub-dimensions of principals' transformational leadership and teachers' CPD. To better identify the more precise mechanism underlying the relationship between principals' transformational leadership and CPD, future study needs to expand the understanding of relationships between sub-dimensions of transformational leadership and teachers' CPD.

Third, in the context of planned behavior theory (TPA), any behavior is conceptualized in action and target [82]. For example, regarding teachers' CPD in ESD topic, teachers' CPD is a specific behavior, whereas ESD is a target. The author analyzed whether the teachers' attitudes toward ESD (target), not the attitudes toward CPD, mediate the relationship between the principal's transformational leadership and the teachers' CPD to clarify for teachers to participate in CPD related to ESD topic. In future research, teachers' attitudes toward CPD need to be included and tested to elucidate linkage in the relationship between the principal's transformational leadership and teachers' CPD. Although this study has a few limitations, the author hopes to provide a baseline for future research.

Funding: This research was supported by the Daegu University Research Grant, 2017 (20170065).

Institutional Review Board Statement: The study was conducted according to the guidelines of the Declaration of Helsinki.

Informed Consent Statement: Informed consent was obtained from all subjects involved in the study.

Data Availability Statement: Not applicable.

Conflicts of Interest: The author declares no conflict of interest.

\section{References}

1. Davies, B. Rethinking strategy and strategic leadership in schools. Educ. Manag. Adm. 2003, 31, 295-312. [CrossRef]

2. Edwards, M.; Green, K.; Lyons, C.; Rogers, M.; Swords, M. The effects of cognitive coaching and nonverbal classroom management on teacher efficacy and perceptions of classroom culture. In Proceedings of the Annual Meeting of the American Educational Research Association, San Diego, CA, USA, 13-17 April 1998.

3. Licklider, B. The effects of peer coaching cycles on teacher use of a complex teaching skill and teachers' sense of efficacy. J. Pers. Eval. Educ. 1995, 9, 55-68. [CrossRef]

4. Louis, K.; Marks, H. Does professional community affect the classroom? Teachers' work and student experience in restructuring schools. Am. J. Educ. 1998, 106, 532-575. [CrossRef]

5. Guskey, T. Professional development and teacher change. Teach. Teach. 2002, 8, 381-391. [CrossRef]

6. Ryu, J.; Suh, Y.; Jeong, J. The effect of professional learning community of teachers at vocational high school on learner-centered instruction. J. Korean Teach. Educ. 2021, 38, 223-244.

7. Smylie, M.; Hart, A. School leadership for teacher learning and change: A human and social capital development perspective. In Handbook of Research on Educational Administration, 2nd ed.; Murphy, J., Louis, K.S., Eds.; Jossey-Bass: San Francisco, CA, USA, 1999; pp. 421-441.

8. Komba, W.L.; Nkumbi, E. Teacher professional development in Tanzania: Perceptions and practices, CICE Hiroshima University. J. Int. Coop. Educ. 2008, 11, 67-83.

9. Thoonen, E.E.J.; Sleegers, P.J.C.; Oort, F.J.; Peetsma, T.T.D.; Geijsel, F.P. How to improve teaching practices: The role of teacher motivation, organizational factors, and leadership practices. Educ. Adm. Q. 2011, 47, 496-536. Available online: http:// gencakademik.net/wp-content/uploads/2021/03/ornek-yabanci-makale-analizi-1.pdf (accessed on 18 June 2021). [CrossRef] 
10. Geijsel, F.P.; Sleegers, P.J.C.; Stoel, R.D.; Krüger, M.L. The effect of teacher psychological, school organizational and leadership factors on teachers' professional learning in Dutch schools. Elem. Sch. J. 2009, 109, 406-427. [CrossRef]

11. Ibrahim, N.A.; Hamzah, M.I.M.; Wahab, J.L.A. Impact of Transformational Leadership on Professional Learning Community: Mediating Role of Emotional Intelligence. Int. J. Psychosoc. Rehabil. 2020, 24, 2442-2450.

12. Gaikhorst, L.; März, V.; Pré, R.; Geijsel, F. Workplace conditions for successful teacher professional development: School principals' beliefs and practices. Eur. J. Educ. 2019, 54, 605-620. Available online: https://onlinelibrary.wiley.com/doi/pdf/10.1111/ejed.12 366 (accessed on 21 June 2021). [CrossRef]

13. Drago-Severson, E. New opportunities for principal leadership: Shaping school climates for enhanced teacher development. Teach. Coll. Rec. 2012, 114, 1-44.

14. Bass, B. From transactional to transformational leadership: Learning to share the vision. Organ. Dyn. 1990, 18, 19-31. [CrossRef]

15. Henderson, K.; Tilbury, D. Whole-School Approaches to Sustainability: An International Review of Sustainable School Programs; Report Prepared by the Australian Research Institute in Education for Sustainability (ARIES) for The Department of the Environment and Heritage; Australian Government: Canberra, Australia, 2004.

16. Redman, E.; Wiek, A.; Redman, A. Continuing professional development in sustainability education for K-12 teachers: Principles, programme, applications, outlook. J. Educ. Sustain. Dev. 2018, 12, 59-80. [CrossRef]

17. Kadji-Beltran, C.; Zachariou, A.; Stevenson, R. Leading sustainable schools: Exploring the role of primary school principals. Environ. Educ. Res. 2012, 19, 303-323. [CrossRef]

18. Pittman, J. Living Sustainably through Higher Education: A Whole systems design approach to organizational change. In Higher Education and the Challenge of Sustainability; Corcoran, P.B., Wals, A.E.J., Eds.; Springer: Dordrecht, The Netherlands, 2004. [CrossRef]

19. Korean Ministry of Education. The National Curriculum; Korean Ministry of Education: Sejong, Korea, 2015.

20. Leithwood, K.; Jantzi, D.; Steinbach, R. Leadership and other conditions which foster organizational learning in schools. In Organizational Learning in Schools; Leithwood, K., Louis, K.S., Eds.; Swets \& Zeitlinger: Lisse, The Netherlands, 1998 ; pp. 67-92.

21. Youngs, P.; King, M. Principal leadership for professional development to build school capacity. Educ. Adm. Q. 2002, 38, 643-670. [CrossRef]

22. Marks, H.; Printy, S. Principal Leadership and School Performance: An integration of transformational and instructional leadership. Educ. Adm. Q. 2003, 39, 370-397. Available online: http://1st-iiep.iiep-unesco.org/cgi-bin/wwwi32.exe/[in=epidoc1 .in] $/$ t2000 $=018908 /(100)$ (accessed on 18 May 2020). [CrossRef]

23. Payne, D.; Wolfson, T. Teacher professional development: The principal's critical role. NASSO Bull. 2000, 84, 13-21. [CrossRef]

24. Postholm, M.B. A completed research and development work project in school: The teachers' learning and possibilities, premises and challenges for further development. Teach. Teach. Educ. 2011, 27, 560-568. [CrossRef]

25. Geijsel, F.; Sleegers, P.; Leithwood, K.; Jantzi, D. Transformational leadership effects on teacher commitment and effort toward school reform. J. Educ. Adm. 2003, 41, 228-256. [CrossRef]

26. Hipp, K. Documenting the effects of transformational leadership on teacher efficacy. In Proceedings of the Annual Meeting of the American Educational Research Association, Chicago, IL, USA, 24-28 March 1997. ERIC Document Reproduction Service No. ED 407734.

27. Sharma, R.; Singh, S. Transformational leadership style and self-efficacy among teaching professionals. Int. J. Indian Psychol. 2017, 4, 139-147.

28. Ninković, S.; Knežević Florić, O. Transformational school leadership and teacher self-efficacy as predictors of perceived collective teacher efficacy. Educ. Manag. Adm. Leadersh. 2018, 46, 49-64. [CrossRef]

29. Ryan, H. An Examination of the Relationship between Teacher Efficacy and Teachers' Perceptions' of Their Principal's Leadership Be-haviors. Doctoral Dissertation, University of North Texas, Denton, TX, USA, May 2007. Available online: http:/ / digital.library. unt.edu/ark: /67531/metadc3620/ (accessed on 7 June 2021).

30. Ross, J.; Gray, P. Transformational leadership and teacher commitment to organizational values: The mediating effects of collective teacher efficacy. Sch. Eff. Sch. Improv. 2006, 17, 179-199. [CrossRef]

31. Liu, S.; Hallinger, P.; Feng, D. Supporting the professional learning of teachers in China: Does principal leadership make a difference? Teach. Teach. Educ. 2016, 59, 79-91. [CrossRef]

32. Karacabey, M.F.; Bellibaş, M.Ş.; Adams, D. Principal leadership and teacher professional learning in Turkish schools: Examining the mediating effects of collective teacher efficacy and teacher trust. Educ. Stud. 2020, 1-20. [CrossRef]

33. Hosseingholizadeh, R.; Amrahi, A.; El-Farr, H. Instructional leadership, and teacher's collective efficacy, commitment, and professional learning in primary schools: A mediation model. Prof. Dev. Educ. 2020, 1-18. [CrossRef]

34. Hoy, W.K.; Woolfolk, A.E. Teachers' sense of efficacy and the organizational health of schools. Elem. Sch. J. 1993, 93, 355-372. [CrossRef]

35. Raudenbush, S.; Rowen, B.; Cheong, Y. Contextual effects on the self perceived efficacy of high school teachers. Sociol. Educ. 1992, 65, 150-167. [CrossRef]

36. Lee, V.; Dedick, R.; Smith, J. The effect of the social organization of schools on teachers' efficacy and satisfaction. Sociol. Educ. 1991, 64, 190-208. [CrossRef]

37. Newmann, F.M.; Rutter, A.R.; Smith, M.S. Organizational factors that affect school sense of efficacy, community, and expectations. Sociol. Educ. 1989, 62, 221-238. [CrossRef] 
38. Gan, D.; Gal, A. Self-efficacy for promoting EfS among pre-service teachers in Israel. Environ. Educ. Res. 2018, $24,1062-1075$. [CrossRef]

39. Davies, B. Developing sustainable leadership. Manag. Educ. 2007, 21, 4-9. [CrossRef]

40. Harris, A. Distributed School Leadership: Developing Tomorrow's Leaders; Routledge: London, UK, 2008.

41. Birney, A.; Reed, J. Sustainability and Renewal: Findings from the Leading Sustainable Schools Research Project. Available online: http:/ / dera.ioe.ac.uk/2061/1/download\%3Fid=33296\&filename=sustainability-and-renewal-full-report.pdf (accessed on 27 June 2021).

42. Day, C.; Harris, A. Teacher leadership, reflective practice, and school improvement. In Second International Handbook of Educational Leadership and Administration; International Handbooks of Education; Leithwood, K., Ed.; Springer: Dordrecht, The Netherlands, 2002; Volume 8, pp. 957-977. [CrossRef]

43. Leithwood, K.; Louis, K.S.; Anderson, S.; Wahlstrom, K. How Leadership Influences Student Learning; The Wallace Foundation: New York, NY, USA, 2004.

44. Lambrechts, W.; Verhulst, E.; Rymenams, S. Professional development of sustainability competences in higher education: The role of empowerment. Int. J. Sustain. High. Educ. 2017, 18, 697-714. [CrossRef]

45. Glatthorn, A. Cooperative professional development: Peer-centered options for teacher growth. Educ. Leadersh. 1987, 45, 31-35.

46. Guthrie, J.P.; Schwoerer, C.E. Individual and contextual influences on self-assessed training needs. J. Organ. Behav. 1994, 15, 405-422. [CrossRef]

47. Bandura, A. Self-efficacy mechanism in human agency. Am. Psychol. 1982, 37, 122. Available online: https://www.uky.edu/ $\sim\{\}$ eushe2/Bandura/Bandura1982AP.pdf (accessed on 29 July 2020).

48. Lohman, M. Factors influencing teachers' engagement in informal learning activities. J. Workplace Learning 2006, 18, 141-156. [CrossRef]

49. Biasutti, M.; Frate, S. A validity and reliability study of the attitudes toward sustainable development scale. Environ. Educ. Res. 2017, 23, 214-230. [CrossRef]

50. Cordina, M.; Mifsud, M.C. A Quantitative Study of Maltese Primary School Teachers and Their Perceptions towards Education for Sustainable Development. US-China Edu. Rev. B 2016, 6, 329-349. [CrossRef]

51. Shephard, K. Higher Education for Sustainability: Seeking affective learning outcomes. Int. J. Sustain. High. Educ. 2008, 9, 87-98. [CrossRef]

52. Maidou, A.; Plakitsi, K.; Polatoglou, H.M. Knowledge, perceptions and attitudes on education for sustainable development of pre-service early childhood teachers in Greece. World J. Educ. 2019, 9, 1-15. [CrossRef]

53. Tomas, L.; Girgenti, S.; Jackson, C. Pre-service teachers' attitudes toward education for sustainability and its relevance to their learning: Implications for pedagogical practice. Environ. Educ. Res. 2017, 23, 324-347. [CrossRef]

54. Koh, W.L.; Steers, R.M.; Terborg, J.R. The effects of transformational leadership on teacher attitudes and student performance in Singapore. J. Organ. Behav. 1995, 16, 319-333. [CrossRef]

55. Ling, S.; Ling, M. The influence of transformational leadership on teacher commitment towards organization, teaching profession, and student learning in secondary schools in Miri, Sarawak, Malaysia. Edu. Int. J. Educ. Stud. 2012, 4, 155-178.

56. Ismail, A.; Mydin, A. The Impact of transformational leadership and commitment on teachers' innovative behaviour, advances in social science. Educ. Humanit. Res. 2019, 304, 426-430.

57. Heystek, J.; Terhoven, R. Motivation as critical factor for teacher development in contextually challenging underperforming schools in South Africa. Prof. Dev. Educ. 2014, 41, 1-16. [CrossRef]

58. Amos, N.; Benton, G. Teacher attitudes toward staff development and related activities in a rural educational consortium. In Proceedings of the 1988 annual meeting of the Mid-South Educational Research Association; Louisville, KY, USA, 8-11 November 1988. Available online: https:/ / files.eric.ed.gov/fulltext/ED304261.pdf (accessed on 5 April 2021).

59. Polyzopoulou, T.K. Greek teachers' attitudes toward the inclusion of students with special educational needs. Am. J. Educ. Res. 2014, 2, 208-218. [CrossRef]

60. Weisel, A.; Dror, O. School climate, sense of efficacy and Israeli teachers' attitudes toward inclusion of students with special needs. Educ. Citizsh. Soc. Justice 2006, 1, 157-174. [CrossRef]

61. Soodak, L.C.; Podell, D.M.; Lehman, L.R. Teacher, student, and school attributes as predictors of teachers' responses to inclusion. J. Spec. Educ. 1998, 31, 480-497. [CrossRef]

62. Malinen, O.P.; Savolainen, H.; Xu, J. Beijing in-service teachers' self-efficacy and attitudes towards inclusive education. Teach Teach. Educ. 2012, 28, 526-534. [CrossRef]

63. Soka, L.; Sharma, U. Canadian in-service teachers' concerns, efficacy, and attitudes about inclusive teaching. Except. Educ. Int. 2014, 23, 59-71. [CrossRef]

64. Lee, C.; Krapfl, L. Teaching as you would have them teach: An effective elementary science teacher preparation program. J. Sci. Teach. Educ. 2002, 13, 247-265. [CrossRef]

65. Sagdiç, A.; Şahin, E. An assessment of Turkish elementary teachers in the context of education for sustainable development. Int. Electron. J. Environ. Educ. 2016, 6, 141-155. [CrossRef]

66. Tschannen-Moran, M.; Woolfolk, A. Teacher efficacy: Capturing an elusive construct. Teach. Teach. Educ. 2001, 17, 783-805. [CrossRef] 
67. Park, H.; Kang, J.; Lee, S. Development of the KEDI Comprehensive Tests, 2nd ed.; KEDI (Korean Educational Development Institute): Seoul, Korea, 2006.

68. OECD. TALIS 2013 Results: An International Perspective on Teaching and Learning; OECD: Paris, France, 2014.

69. Hooper, D.; Coughlan, J.; Mullen, M. Structural Equation Modelling: Guidelines for determining model fit. Electron. J. Bus. Res. Methods 2008, 6, 53-60.

70. Asif, M.; Miao, Q.; Jameel, A.; Manzoor, F.; Hussain, A. How ethical leadership influence employee creativity: A parallel multiple mediation model. Curr. Psychol. 2020, 1-17. [CrossRef]

71. Schreiber, J.B. Core reporting practices in structural equation modeling. Res. Soc. Adm. Pharm. 2008, 4, 83-97. [CrossRef]

72. Qing, M.; Asif, M.; Hussain, A.; Jameel, A. Exploring the impact of ethical leadership on job satisfaction and organizational commitment in public sector organizations: The mediating role of psychological empowerment. Rev. Manag. Sci. 2020, 14, 1405-1432. [CrossRef]

73. Asif, M.; Qing, M.; Hwang, J.; Shi, H. Ethical leadership, affective commitment, work engagement, and creativity: Testing a multiple mediation approach. Sustainability 2019, 16, 4489. [CrossRef]

74. Ledermann, T.; Macho, S.; Kenny, D.A. Assessing mediation in dyadic data using the actor-partner interdependence model. Struct. Equ. Modeling A Multidiscip. J. 2011, 18, 595-612. [CrossRef]

75. Hayes, A. Introduction to Mediation, Moderation, and Conditional Process Analysis: A Regression-Based Approach; Guilford Press: New York, NY, USA, 2013.

76. Hayes, A.; Scharkow, M. The relative trustworthiness of inferential tests of the indirect effect in statistical mediation analysis: Does method really matter? Psychol. Sci. 2013, 24, 1918-1927. [CrossRef] [PubMed]

77. Shrout, P.; Bolger, N. Mediation in experimental and nonexperimental studies: New procedures and recommendations. Psychol. Methods 2002, 7, 422-445. [CrossRef]

78. Hair, J.F.; Black, W.C.; Balin, B.J.; Anderson, R.E. Multivariate Data Analysis, 7th ed.; Pearson: New York, NY, USA, 2010. Available online: https:/ / www.pdfdrive.com/multivariate-data-analysis-7th-edition-d156708931.html (accessed on 28 July 2020).

79. Awang, Z. Structural Equation Modeling Using Amos Graphic; UiTM Press: Shah Alam, Malaysia, 2012.

80. Kline, R.B. Principles and Practice of Structural Equation Modeling, 2nd ed.; Guilford Press: New York, NY, USA, 2005.

81. Forza, C.; Filippini, R. Tqm impact on quality conformance and customer satisfaction: A causal model. Int. J. Prod. Econ. 1998, 55, 1-20. [CrossRef]

82. Ajzen, I. The theory of planned behavior. Organ. Behav. Hum. Decis. Processes. 1991, 50, 179-211. [CrossRef] 